\title{
Nut en noodzaak van een algemene codificatie van bestuursrecht
}

\author{
Rolf Ortlep, Willemien den Ouden, dr. Ymre Schuurmans Ph.D., Albertjan \\ Tollenaar, Gerrit van der Veen en Johan Wolswinkel
}

\author{
Aanbevolen citeerwijze bij dit artikel \\ Rolf Ortlep, Willemien den Ouden, dr. Ymre Schuurmans Ph.D. e.a. , 'Nut en noodzaak \\ van een algemene codificatie van bestuursrecht', NALL februari 2014, DOI: \\ 10.5553/NALL/.000020
}

\section{Inleiding}

In Nederland hebben wij inmiddels zo'n twintig jaar ervaring met de codificatie van algemeen bestuursrecht in de Algemene wet bestuursrecht (Awb). Het functioneren van die codificatie in de rechtspraktijk is al verschillende malen, meer of minder gedetailleerd, onderzocht. Zo verscheen aanvankelijk om de vijf jaar een evaluatierapport, naar aanleiding van de evaluatie van verschillende deelonderwerpen uit de Awb. ${ }^{\mathbf{1}}$ De vijf-, tien- en vijftienjarige verjaardag van de Awb zijn luister bijgezet met congressen en bundels. ${ }^{2}$ De redactie van NALL heeft ten behoeve van een special verschillende auteurs verzocht in een bijdrage het succes - of het uitblijven daarvan - van de derde tranche van de Awb te belichten. Hoe hebben de regels, ingevoerd met de derde tranche in 1998, uitgepakt, zijn de doelstellingen bereikt en wat leert deze terugblik ons over nut en noodzaak van codificatie?

In deze koepelbijdrage leggen wij allereerst verbanden tussen de bevindingen van de vijf verschillende bijdragen over dit thema en bezien wij welke algemene bewegingen in de codificatie zichtbaar zijn (paragraaf 2). Daarna volgt een abstractere beschouwing over factoren die codificatie van algemene regels van bestuursrecht al dan niet succesvol maken (paragraaf 3). Het is zinvol deze ontwikkelingen vervolgens te plaatsen in een Europees verband (paragraaf 4). Binnen de instellingen van de EU wordt immers al langer nagedacht over de wenselijkheid om een algemene regeling te maken voor bestuursrechtelijke procedures op EU-niveau. ${ }^{3}$ Terugkijkend op 20 jaar ervaring met de Awb, bezien wij wat de Europese wetgever mogelijk van de Nederlandse ervaringen kan leren. Maar ook, wat een frisse Europese blik voor bijzonderheden in onze eigen codificatie blootlegt. De bijdrage sluit af met enkele aanbevelingen voor, laten we zeggen, de komende twintig jaar (paragraaf 5).

\section{Bevindingen: het succes van de codificatie van de derde tranche}




\subsection{Inleiding}

Een van de voornaamste doelstellingen van de wetgever met de Awb is om eenheid te brengen in de verscheidenheid van de vele wetten waarin de rechtsverhouding tussen burger en bestuur wordt vormgegeven en genormeerd. De derde tranche van de Awb heeft in dit verband onder meer algemene regels opgeleverd over bekendmaking, subsidies, beleidsregels, handhaving en bestuurlijk toezicht. Over deze vijf onderwerpen zijn bijdragen opgenomen in de NALL-special ter gelegenheid van het 15-jarig jubileum van de derde tranche. ${ }^{4}$ De vijf onderwerpen richten zich in feite op drie aspecten van de rechtsverhouding tussen bestuur en burger: de (vormgeving van de) bevoegdheid van het bestuursorgaan, rechtsfiguren waarmee de uitoefening van die bevoegdheid kan worden vormgegeven en de normen die het bestuursorgaan daarbij in acht moet nemen. 5

In het vervolg van deze paragraaf worden enkele bevindingen uit de afzonderlijke bijdragen samengevat weergegeven, waarbij we ons richten op de grote bewegingen die de codificatie van de Awb teweeg heeft gebracht. Deze bewegingen worden gekarakteriseerd met drie begrippenparen die elkaar tegenspreken: behoud en verandering, vereenvoudiging en complicering, convergentie en divergentie. Aan de hand van deze begrippenparen kunnen wij laten zien hoe de Awb-wetgever worstelt met het vormgeven van de gewenste rechtsverhouding, hoe deze vormgeving de rechtspraktijk verandert of juist niet, en hoe de bijzondere wetgever reageert op de veralgemenisering van de rechtsverhouding in de Awb.

\subsection{Behoud en verandering}

Een belangrijk deel van de bepalingen in de derde tranche richt zich op de wijze waarop bestuursorganen hun bestuursbevoegdheden uitoefenen. Een interessante vraag is of de codificatie van deze normen iets heeft veranderd in de uitvoeringspraktijk, dan wel of deze uitvoeringspraktijk zich (n)iets heeft aangetrokken van de verandering van de rechtsnormen. Een verandering van het recht betekent immers niet automatisch een wijziging van de bestuurspraktijk. Het is veeleer andersom: de bestuurspraktijk heeft een natuurlijke hang naar behoud van de status quo, naar inertie. ${ }^{\mathbf{6}}$ Het is vanuit dat perspectief verstandig dat nieuwe wetgeving vaak, waar mogelijk, voortbouwt op bestaande structuren.

Vast staat dat de wetgever met de derde tranche van de Awb op onderdelen wel een verandering heeft beoogd. Bij de codificatie van de beleidsregel is bijvoorbeeld expliciet overwogen dat het wenselijk zou zijn als bestuursorganen hun beleid in beleidsregels zouden vastleggen. Dit zou een verandering van de tot dan geldende bestuurspraktijk betekenen. Uit de bijdrage van Tollenaar over het succes van de codificatie van de beleidsregel ${ }^{7}$ zijn aanwijzingen te vinden dat bestuursorganen tegenwoordig inderdaad vaker beleid in de vorm van een beleidsregel vaststellen. In zoverre heeft de codificatie dus tot verandering geleid.

Een verandering van de bestuurspraktijk is echter niet overal waarneembaar. Zo blijken de bepalingen over het toezicht op bestuursorganen weinig sturing te geven. ${ }^{\mathbf{8}}$ Deze toezichtsbepalingen regelen de wijze waarop een (hoger) bestuursorgaan gebruik kan maken van de bevoegdheid om goedkeuring te onthouden aan besluiten van een ander bestuursorgaan, dan wel deze te schorsen of te vernietigen. Indirect kan deze interventie ook consequenties hebben voor de rechtsbetrekking tussen het bestuursorgaan dat object van 
toezicht is en een derde, die van dat bestuursorgaan een besluit ontvangt. Broeksteeg laat zien dat de gevallen waarin een hoger bestuursorgaan zich bemoeit met de bevoegdheidsuitoefening van een lager bestuursorgaan in aantal gering zijn en vooral consequenties hebben voor de interbestuurlijke verhoudingen tussen de bestuurslagen waartoe de bestuursorganen behoren. Daarbij is interessant dat de Awb wel generieke bevoegdheidsvoorwaarden bevat waaronder het toezichthoudende bestuursorgaan gebruik kan maken van de interventiebevoegdheid: strijd met het recht of het algemeen belang. Broeksteeg constateert echter dat deze bevoegdheidsvoorwaarden weinig richting geven. Die richting is wel gevonden in een Beleidskader - dat wellicht als een beleidsregel zou kunnen worden gezien - waarin als belangrijkste norm is opgenomen dat de vernietiging van besluiten geldt als ultimum remedium. Met de

inwerkingtreding van de Wet revitalisering generiek toezicht is dat uitgangspunt echter weer verlaten, waardoor het toezicht door hogere bestuursorganen aan belang lijkt te hebben gewonnen. Dat kan ook gevolgen hebben voor de rechtspositie van burgers. De huidige constellatie van het toezicht kan er immers toe leiden dat bijvoorbeeld een vergunning voor de bouw van een megastal wordt vernietigd.9 Broeksteeg constateert echter ook dat de toenemende relevantie van het toezicht niet zoveel met de Awb van doen heeft. Dit effect is immers bereikt door harmonisatie via de Wet revitalisering generiek toezicht en de daarmee verband houdende materiële regels over het gebruik van de toezichtsbevoegdheden. Broeksteeg concludeert dat de bepalingen in hoofdstuk 10 Awb nagenoeg geen rol spelen in bestuursrechtelijke procedures over schorsings- en vernietigingsbesluiten. De veranderingen die in de praktijk hebben plaatsgevonden staan dus los van de regeling in de Awb.

Dat de Awb soms veranderingen teweeg wil brengen, maar daarbij stuit op een onveranderlijke praktijk kan ook worden afgeleid uit de bijdrage van Ortlep over de wijziging van de bekendmakingsregel in de derde tranche. ${ }^{\mathbf{1 0}}$ De derde tranche leidde tot de toevoeging van een tweede lid aan artikel 3:41 Awb: indien bekendmaking niet kan geschieden door toezending of uitreiking aan de bekende belanghebbende, geschiedt bekendmaking op een andere geschikte wijze. Bij het - in het kader van de derde tranche - ontwerpen van de afdeling over bestuursdwang kwam bij de regering het inzicht dat bekendmaking door toezending of uitreiking van de beslissing tot bestuursdwang praktisch niet altijd mogelijk is. Die situatie doet zich bijvoorbeeld voor indien de identiteit van de overtreder bij het bestuursorgaan onbekend is of het bestuursorgaan niet beschikt over een (correct) adres. Dit werd gezien als een algemeen probleem dat zich ook kon voordoen bij bekendmaking van andere besluiten. Artikel 3:41, tweede lid, Awb heeft tot een verandering geleid in de zin dat de bestuurspraktijk de ruimte kreeg alternatieve mogelijkheden tot bekendmaking te creëren, zoals door aanplakking van een besluit. Daar staat tegenover dat de bekendmakingsregel van artikel 3:41, eerste lid, Awb (toezending of uitreiking aan de geadresseerde) in de jurisprudentie zo ruim wordt uitgelegd dat er eigenlijk op sommige punten geen noodzaak meer bestaat voor bekendmaking 'op een andere geschikte wijze'. Bovendien, zo belicht Ortlep, leidt moderne elektronische communicatie via 'Mijn SVB' of 'Mijn DUO' tot een geheel andere wijze van bekendmaken, die de wetgever bij de codificatie van de derde tranche nog niet voor ogen stond. In zoverre blijkt de Awb-codificatie een irrelevante contextfactor voor een praktijk die de weg zelf wel vindt.

Datzelfde kan worden gezegd van de afwijking van beleidsregels. Hoewel de Awb als voorwaarde stelt dat het bestuursorgaan slechts kan afwijken van de beleidsregel indien toepassing van de beleidsregel voor belanghebbenden wegens bijzondere omstandigheden onevenredige gevolgen heeft, constateert 
Tollenaar dat noch het bestuursorgaan, noch de rechter zwaar aan deze voorwaarde tilt. Als een beleidsregel naar het oordeel van het bestuursorgaan en de rechter resulteert in onevenredig nadeel, dan is reeds daarin een rechtvaardiging voor een afwijkend besluit gelegen, ondanks de kennelijke afwezigheid van omstandigheden die niet bij vaststelling van de beleidsregel zijn overwogen. In zoverre blijkt de Awb dus niet te hebben geleid tot een verandering van de beoordeling van beslissingen die van een beleidsregel afwijken.

De codificatie van de regels over toezicht en handhaving hebben wel geleid tot een wijziging van de bestuurspraktijk, zo laat Michiels in zijn bijdrage zien. ${ }^{\mathbf{1 1}}$ Deze praktijk was versnipperd, zeker waar het de toezichtsbevoegdheden betrof. De codificatie heeft geleid tot een uniformering van het pakket aan bevoegdheden, dat naderhand zelden door de bijzondere wetgever is ingeperkt. De juridische erkenning van de toezichthouder als bijzondere professie met bijzondere bevoegdheden, is hand in hand gegaan met een verdere professionalisering van deze beroepsgroep. ${ }^{\mathbf{1 2}}$ Natuurlijk is het wat te veel eer om deze professionalisering enkel toe te schrijven aan de Awb, maar duidelijk is wel dat de codificatie van deze bevoegdheden een bijdrage heeft geleverd aan de ontplooiing van de toezichthoudende bestuurstaak.

Ook de bijdrage van Jacobs \& Den Ouden ${ }^{\mathbf{1 3}}$ bevat, ten slotte, een voorbeeld van een rechtsgebied waarop codificatie van algemene regels tot een wijziging van de bestuurspraktijk heeft geleid. In de tijd dat de subsidietitel van de Awb (titel 4.2) werd ontwikkeld, was de subsidiepraktijk zo divers dat echte keuzes door de wetgever moesten worden gemaakt. Om rechtseenheid te bewerkstelligen heeft de wetgever gekozen voor een breed opgezet, door de Raad van State zelfs als 'topzwaar' betiteld, werkstuk dat voor vrijwel alle onderdelen van de rechtspraktijk wijzigingen met zich meebracht. Jacobs \& Den Ouden constateren dat, hoewel de inwerkingtreding van de subsidietitel tot gevolg had dat allerlei juridische aspecten van de subsidieverhouding voortaan op een min of meer uniforme wijze waren geregeld, er vooral op het gebied van de uitvoering van subsidieregelingen belangrijke verschillen bleven bestaan tussen bestuursorganen. In de loop van de tijd is echter ook die veelvormigheid aangepakt. Belangrijk zijn in dat verband geweest de ontwikkeling van een uniform subsidiekader (een beleidsstuk waarin maatregelen voor een eenvoudiger beheer en uitvoering van subsidies werden beschreven) en een regeling van de Minister-President, waarin bepaalde onderdelen van het uniform subsidiekader zijn uitgewerkt. De laatst genoemde regeling is neergelegd in de Aanwijzingen voor subsidieverstrekking. Uit monitoring blijkt dat op rijksniveau inmiddels de meeste subsidies volgens het uniform subsidiekader worden verstrekt en dat ook op decentraal niveau met belangstelling wordt gekeken naar de aanwijzingen.

Op grond van deze ontwikkelingen concluderen Jacobs \& Den Ouden dat de totstandkoming van titel 4.2 Awb een belangrijke factor was voor de harmonisatie van (de uitvoering van het) subsidiebeleid op rijksniveau. De Awbwetgever heeft op dit rechtsgebied veel invloed gehad op de rechtsontwikkeling. Door de subsidietitel en de daarop geënte bijzondere subsidieregelgeving kon veel beter dan voorheen aan het licht komen dat de verschillende bestuursorganen op rijksniveau bij de totstandkoming van subsidieregelgeving en -beleid in veel gevallen voor dezelfde vraagstukken een oplossing moeten vinden. Er ontstond een eenvormig begrippenkader waardoor uitwisseling van kennis en best practices eenvoudiger is geworden. Het streven naar een verbeterde efficiëntie van de uitvoeringspraktijk en kostenbesparingen zijn hier 
óók belangrijke drijfveren geweest voor verandering; zonder gemeenschappelijk juridisch kader waren die echter veel lastiger te bewerkstelligen geweest.

\subsection{Vereenvoudiging en complicering}

In de derde tranche is een aantal 'nieuwe' rechtsfiguren gedefinieerd, waaronder de subsidieverstrekking, de beleidsregel en de handhavingsbeschikkingen (last onder dwangsom en last onder bestuursdwang). De wetgever heeft, juist vanuit de uniformeringsgedachte, zoveel mogelijk gekozen voor materiële definities. Dit impliceert dat niet het opschrift of de aanduiding van het besluit van doorslaggevend belang is voor de kwalificatie, maar de inhoud en materiële werking daarvan. Het is kortom niet van belang of een financiële bijdrage als subsidie wordt aangemerkt, of juist als 'tegemoetkoming' of 'compensatie'. Zodra sprake is van een aanspraak op financiële middelen, met het oog op bepaalde activiteiten van de aanvrager, anders dan als betaling voor aan het bestuursorgaan geleverde goederen of diensten, geldt deze als subsidie, zo blijkt uit artikel 4:21 Awb. Dat de werkelijkheid weerbarstiger is, blijkt onder meer uit de bijdrage van Jacobs \& Den Ouden. Zij constateren dat de bijzondere regelgevers en bestuursorganen het soms behoorlijk ingewikkeld maken, juist door financiële bijdragen niet als subsidie aan te merken, waar het wel om subsidies gaat. De tegengestelde situatie komt ook voor: een bijzondere regelgever merkt een financiële bijdrage aan als een subsidie, terwijl deze bijdrage niet aan de elementen van de subsidiedefinitie voldoet. Wanneer geschillen ontstaan, wordt het in zo'n geval voor de rechter erg lastig het juiste wettelijke kader vast te stellen en, als hij dat toch doet, om het voorliggende geschil op te lossen. Tot slot blijkt de Awb-wetgever zelf ook belangrijke uitzonderingen op het subsidiebegrip te hebben aangebracht. Zo vallen aanspraken die ontstaan op basis van belastingvoorschriften niet onder de reikwijdte van de subsidietitel (art. 4:21 Awb, tweede lid, sub a), terwijl fiscale stimuleringsmaatregelen in de praktijk vaak nauwelijks zijn te onderscheiden van subsidieregelingen en ook door dezelfde bestuursorganen worden uitgevoerd. ${ }^{\mathbf{4}}$

Voor de beleidsregel geldt iets vergelijkbaars. Ook deze rechtsfiguur is gecodificeerd met een materiële definitie, waarbij uiteindelijk de bevoegdheid om beleidsregels vast te stellen bepalend is voor de vraag of de vastgestelde regel heeft te gelden als beleidsregel. Ontbreekt de beleidsregelbevoegdheid, dan geldt de gedragslijn hoogstens als richtlijn, tenzij het tot beleidsregelgeving bevoegde bestuursorgaan de richtlijn overneemt en vaststelt als 'eigen' beleidsregel. In dit geval is het onderscheid van belang vanwege de sterkere binding aan beleidsregels ten opzichte van richtlijnen. ${ }^{\mathbf{1 5}}$

De beide voorbeelden illustreren dat waar de wetgever probeert een rechtsfiguur te definiëren en te codificeren, er bijna per definitie discussies ontstaan over de precieze reikwijdte van de definitie. Bovendien wijken bijzondere wetgevers af van de Awb-definities in formele wetgeving, terwijl lagere regelgevers en bestuursorganen (al dan niet bewust) 'mist' creëren door de rechtsfiguur anders te benoemen of niet toe te passen. Ten slotte ziet de Awb-wetgever er zelf ook geen been in om - op pragmatische gronden - belangrijke beleidsterreinen uit te zonderen. Dat maakt het rechtskader er dus niet in alle gevallen eenvoudiger op. Codificatie leidt zodoende niet alleen tot vereenvoudiging, maar ook tot complicering.

\subsection{Convergentie en divergentie}


In de Awb wordt doorgaans gekozen voor de systematiek waarin een bepaald soort besluit van een algemene regeling wordt voorzien, maar de bevoegdheidstoekenning voorbehouden blijft aan de bijzondere wetgever. Die bepaalt bij wettelijk voorschrift aan welk bestuursorgaan de betreffende bevoegdheid wordt toegekend en vaak kan in die bijzondere wet ook gebruik worden gemaakt van mogelijkheden die bepalingen van regelend, aanvullend en facultatief recht bieden. Een voorbeeld daarvan biedt titel 5.3 Awb inzake herstelsancties. Daarin is de last onder bestuursdwang gedefinieerd (art. 5:21 Awb), maar een bevoegdheidstoekenning vindt in deze titel niet plaats. Die grondslag moet de bijzondere wet bieden, waarna de Awb regelt hoe de bevoegdheid kan worden uitgeoefend en waar een bestuursdwangbeschikking aan moet voldoen. Daarbij voorziet de Awb ook in enkele accessoire bevoegdheden, zoals de bevoegdheid om in plaats van bestuursdwang een last onder dwangsom op te leggen (art. 5:32 Awb). Ook voorziet de Awb in het toekennen van een 'standaardpakket' onderzoeksbevoegdheden aan degenen die door het bestuursorgaan als toezichthouder zijn aangemerkt.

Interessant is de te signaleren spanning tussen het algemeen deel (de Awb) en de bijzondere wetten waarin de bestuursdwangbevoegdheid en toezichtsbevoegdheden zijn opgenomen. Zoals Michiels constateert heeft de verzameling van de handhavingsbepalingen in de Awb onmiskenbaar geleid tot een vereenvoudiging van de voorheen versnipperde regels die de vergelijkbare bevoegdheid regelden. ${ }^{\mathbf{1 6}}$ Opvallend is evenwel dat met het overhevelen van bijvoorbeeld de regels over de uitoefening van een bestuursdwangbevoegdheid de wetgever in een aantal bijzondere wetten een interventie, die qua vorm sterk lijkt op het uitoefenen van bestuursdwang (namelijk: door feitelijk handelen een overtreding beëindigen), expliciet niet aanmerkt als het uitoefenen van bestuursdwang. ${ }^{17}$ De bijzondere wetgever lijkt soms dus huiverig om de bevoegdheden van het bestuursorgaan te uniformeren naar het model van de Awb. Het gevolg: divergentie met een variatie aan vergelijkbare rechtsfiguren. De parallel met de hiervoor beschreven ervaringen in het subsidierecht, waarin financiële verstrekkingen die sterk op subsidies lijken (lees: die subsidies zijn) toch een andere naam krijgen, is opvallend te noemen.

In sommige gevallen heeft de codificatie echter wel duidelijk convergerende effecten. Michiels laat dit zien ten aanzien van de bevoegdheden die samenhangen met het uitoefenen van toezicht. Hij constateert dat de bijzondere wetgever vrijwel nooit een uitzondering maakt op de bevoegdheden die de Awb aan een toezichthouder toekent. Het gevolg: de toezichthouder die voorheen over beperkte onderzoeksbevoegdheden beschikte op grond van bijzondere regelgeving, beschikt sinds de inwerkingtreding van de Awb over een aanmerkelijk groter arsenaal van bevoegdheden. In de bekostigingswetgeving is, na inwerkingtreding van de subsidietitel van de Awb, iets vergelijkbaars geconstateerd. ${ }^{\mathbf{1 8}}$ Dat roept de vraag op of een regeling van bestuursbevoegdheden in een algemene wet niet meer risico's geeft op 'overbevoegdheid' van het bestuur, dan bijzondere wetgeving (op maat).

\subsection{Tussenconclusie}

De verschillende bijdragen over de ontwikkelingen na invoering van de derde tranche illustreren tot welke effecten een algemene codificatie in de Awb kan leiden. Hoewel de Awb verschillende doelstellingen kent, is het niet zo dat bij de codificatie van afzonderlijke onderwerpen al die doelstellingen tegelijk worden behartigd. Soms staat codificatie van een reeds bestaande praktijk voorop (zoals bij interbestuurlijk toezicht), dan weer beoogt de wettelijke regeling vooral een 
rechtsfiguur vorm te geven, waarop het bestuursrecht en de uitvoeringspraktijk nog onvoldoende vat hebben gekregen (zoals bij de subsidietitel het geval was). De mate waarin de regeling in de Awb leidt tot een verandering van de rechtspraktijk, hangt mede af van de doelstelling die aanvankelijk voorop heeft gestaan. Bij het primaire streven tot codificatie van een reeds bestaande praktijk, is de sturende werking van de Awb per definitie beperkt. Toch zien we in breder verband dat van de Awb vaak maar een beperkte sturende werking uitgaat, ook waar sturing wel de intentie van de wetgever was. Daarvoor zijn verschillende oorzaken aan te wijzen: soms loopt de praktijk voor op de regeling, bijvoorbeeld omdat door technologische ontwikkelingen een andere bekendmakingspraktijk ontstaat dan destijds voorzien. Soms ligt de sturende werking meer buiten de Awb in de materiële regelgeving (of het beleid), waarin de meer inhoudelijke keuzes worden gemaakt ten aanzien van de aanwending van bepaalde bevoegdheden (interbestuurlijk toezicht en subsidie). Soms is de bijzondere formele wetgever niet overtuigd en worden (delen van) Awb-wetgeving buiten toepassing verklaard.

$\mathrm{Al}$ met al zien wij bij het streven naar uniformering bijna automatisch een onderstroom ontstaan. Waar de wetgever probeert een rechtsfiguur te definiëren en te codificeren, lijkt dat al snel te leiden tot een ontwijkende reactie bij de bijzondere wetgever of het bestuur. Bijzondere wetgevers wijken af van de Awbdefinities in formele wetgeving, lagere regelgevers compliceren de praktijk door de rechtsfiguur anders te benoemen of niet toe te passen. Zo ontstaan er regelmatig 'alternatieve' rechtsfiguren, waarop de Awb-normen lastig zijn toe te passen. Codificatie leidt zodoende niet alleen tot vereenvoudiging, maar ook tot complicering, omdat een werkelijk geüniformeerde en geharmoniseerde praktijk uitblijft.

\section{Beschouwing: het succes van een algemene codificatie}

\subsection{Inleiding}

Na deze beschouwing naar aanleiding van de derde tranche van de Awb, verruimen wij de blik. In deze paragraaf bezien wij de algemene wetgevingstendensen rond de Awb en bekijken wij wat in de toekomst van verdere aanpassingen mag worden verwacht, mede aan de hand van enkele codificatielessen rond het Burgerlijke Wetboek (paragraaf 3.5). Als opmaat voor die beschouwing behandelt paragraaf 3.2 eerst kort de voordelen die in het algemeen aan codificatie worden toegedicht. Vervolgens bezien wij welk type regels in de loop van de tijd 'succesvol' is gebleken en (blijvend) in de Awb een plaats behoeft. Meer in het bijzonder hebben we ons daarbij de vraag gesteld of 'het beste gecodificeerde algemene bestuursrecht' procedureel recht betreft (paragraaf 3.3) en of dat enkel basisregels geeft (paragraaf 3.4).

Bij dergelijke waarderende uitspraken past uiteraard de nodige voorzichtigheid. In de eerste plaats maken we de kanttekening dat de door ons gehanteerde begrippen als 'procedureel recht' en 'basisregels' of 'algemene regels' zich lastig laten definiëren. Het is eenvoudiger tegenover deze begrippen een antoniem te plaatsen. Tegenover 'procedureel recht' staat 'materieel of substantieel recht' en tegenover 'algemene regels' staan 'specifieke regels'. Tussen die uitersten bevindt zich een grijs gebied waarin regels een tweeledig karakter hebben. Zo bevat de Awb verschillende spelregels, die aangeven hoe een handeling dient plaats te vinden (zoals de legitimatie door een toezichthouder bij aanvang of de bekendmakingswijze van een besluit). Die regels zijn enerzijds procedureel (hoe doen we het?), maar anderzijds kunnen zij niet los worden gezien van de inhoud 
van het spel (waarom doen we het zo?). De door ons gehanteerde begrippen 'procedureel recht', 'materieel recht', 'algemene regels' en 'specifieke regels' hebben in deze bijdrage vooral een ordenende functie en maken het mogelijk een debat te voeren over de aard van het gewenste Awb-recht. De begrippen hebben niet tot doel afzonderlijk Awb-artikelen strikt te scheiden langs definitielijnen en in exacte categorieën in te delen. Grofweg gezegd verstaan wij onder procedureel recht zowel het recht dat de procesvoering voor de bestuursrechter normeert, als het recht dat de totstandkomingswijze van een besluit regelt. ${ }^{19}$ Algemene regels geven normen die (potentieel) op een groot aantal rechtsgebieden van toepassing zijn. Met specifieke regels duiden we op regels die slechts op een enkel rechtsgebied de rechtsbetrekking normeren. In de tweede plaats moet de kanttekening worden gemaakt dat de mate van waardering voor bepaalde onderdelen van de Awb mede lijkt af te hangen van de expertise van de waarderende bestuursrechtjurist. ${ }^{\mathbf{2 0}}$ In de derde plaats is het lastig om in het algemeen 'de waardering' van 'de Awb' te geven. De aard van de codificatie en de daarbij nagestreefde doelen hebben per periode en per onderwerp behoorlijke verschillen laten zien. Waar de wetgever aanvankelijk een grote slag moest maken om in de jurisprudentie ontwikkelde leerstukken te codificeren en bijzondere regels uit verschillende materiële wetten te uniformeren, lijken de twee doelstellingen van harmonisatie en codificatie in de latere jaren minder aandacht te behoeven. De naderhand geïntroduceerde Awbnormen zijn veeleer meer specifiek en modificerend van aard. Dat betekent dat een waardering van 'algemene regels' in de Awb in de eerste tranches anders kan liggen dan een waardering in latere tranches of aanvullende wetgeving.

\subsection{Voordelen van codificatie}

De voordelen van een codificatie van algemeen bestuursrecht zijn eerder belicht, onder andere in 1996 door Scheltema. ${ }^{\mathbf{2 1}}$ Hoewel het codificeren geen garantie geeft dat het recht ook kenbaar is voor de rechtssubjecten, bevordert het de toegang tot het recht. Doordat er met codificatie samenhang in de regels wordt gebracht, kunnen verbanden worden gelegd die bij losse regels niet zichtbaar zijn. Het belang van het aanbrengen van een systeem door middel van codificatie mag niet worden onderschat. G.A. van Poelje had gelijk waar hij schreef: 'Iedere wetenschap intusschen heeft behoefte aan een bepaald systeem; aan een zekere indeeling en ordening, waardoor het geheel van de daarbinnen vallende verschijnselen kan worden overzien en beheerscht. De systematiek is een onmisbaar hulpmiddel ter beheersching van de stof.' ${ }^{22}$ Ook Schueler benadrukt dat in zijn bijdrage aan de bundel ' 15 jaar Awb'. ${ }^{23}$ Hij wijst er onder meer op dat de vaste terminologie van de Awb ervoor zorgt dat verschillende besluitvormingstrajecten vrij gemakkelijk op elkaar kunnen worden afgestemd en dat rechtsvragen die nieuwe regelgeving voortbrengt, gemakkelijk in een systeem kunnen worden ingekaderd. Een ander voordeel van codificatie dat Scheltema heeft benoemd, is dat daarmee de overtuigingskracht van de regels wordt vergroot. Door een systematische ordening van regels wordt de willekeur in het recht verkleind; gelijke gevallen worden op basis van hetzelfde recht zo veel mogelijk gelijk behandeld, hetgeen bijdraagt aan de overtuigingskracht van het recht. Tot slot wijst Scheltema erop dat door codificatie de kwaliteit van het recht wordt verhoogd. Zij dwingt immers tot een systematische behandeling van problemen. In het verlengde daarvan bevordert codificatie de discussie over de inhoud van de regels. 'Doordat zij', aldus Scheltema, 'vanwege hun algemene strekking belangrijker en bekender zijn, komt er ook meer kritiek en discussie op gang'. ${ }^{24}$ Dat was ook de conclusie die Polak in 2010 trok in zijn evaluatie van 15 
jaar Awb-procesrecht. Polak beschrijft dat het werken met één algemeen bestuursprocesrecht natuurlijk niet betekende dat verschillen tussen de bestuursrechtelijke kolommen van de ene op de andere dag verdwenen. Wel kwam een dynamisch proces op gang, waarbij de toepassing van dat procesrecht steeds evolueerde en waarbinnen de rechtspraak van de hoogste

bestuursrechters naar elkaar toegroeide. Op die manier heeft de Awb een proces naar meer eenheid van recht in gang gezet. ${ }^{25}$

Samenvattend worden in het algemeen vier voordelen verbonden aan codificatie benoemd: 1. toegang tot en kenbaarheid van het recht, 2. ordening c.q. systematisering van het recht, 3. overtuigingskracht van het recht c.q. het bestrijden van willekeur en 4. kwaliteit van het recht. Mogelijke nadelen die aan codificatie zouden kunnen kleven, blijven doorgaans onbenoemd.

\subsection{De Awb: vooral procedureel recht?}

Eenvoudig gezegd bestaat de Awb uit regels van procedureel recht en algemene regels voor de uitoefening van (al dan niet specifieke) bevoegdheden van het bestuur. Wie de Awb openslaat ziet direct dat eerstgenoemde regels een zeer groot deel innemen. Dat is ook logisch, omdat op het gebied van het procesrecht de behoefte aan harmonisatie en codificatie reeds lange tijd bestond. De voorloper van de Awb, de Wet administratieve rechtspraak overheidsbeschikkingen (Wet arob), zag voornamelijk op het procesrecht. Gezien dat voorwerk lag het voor de hand om in een meer algemene codificatie in ieder geval ook het procesrecht neer te leggen. Bovendien speelt de aard van het recht een rol. Het procedurele recht in de hoofdstukken 6, 7 en 8 Awb bevat met name dwingend recht. Anders dan bij de daaraan voorafgaande hoofdstukken, is het niet de bedoeling dat in bijzondere wetten allerhande aanvullende bepalingen de regulering van het proces verfijnen of specificeren. Daardoor is het procesrecht, in verhouding tot andere delen van de Awb, omvangrijk. 'Het beste gecodificeerde algemene bestuursrecht is procesrecht' is echter een stelling die tot de nodige discussie kan leiden.

De vraag is immers of de Awb-wetgever niet vaak blijft hangen in bepalingen van procesrechtelijke en technische aard om de moeilijke materiële keuzes te kunnen ontwijken? De meer formele algemene beginselen van behoorlijk bestuur staan vanaf het begin grotendeels in de Awb. Is de rechtsontwikkeling rond meer materiële beginselen (inmiddels) niet zo ver dat ook deze zich voor codificatie lenen? Burgers doen bijvoorbeeld zeer regelmatig een beroep op het gelijkheidsen het vertrouwensbeginsel. ${ }^{\mathbf{2 6}}$ Het bevreemdt dat een wet, die de basisnormen van de rechtsverhouding tussen bestuur en burger beoogt vast te leggen, deze belangrijke en in de jurisprudentie uitgewerkte normen niet omvat. ${ }^{\mathbf{2 7}}$ Is juist bij dit soort normen de toegang tot en kenbaarheid van het recht niet van uitermate groot belang? Zeker als een beroep op dergelijke materiële beginselen in de praktijk niet vaak succesvol is, dringt het voorlichtende codificatiebelang zich op, net als het belang van de overtuigingskracht van het recht. Natuurlijk kan daartegen worden ingebracht dat slechts een hoofdregel kan worden gecodificeerd en dat het van de aard van het materiële recht afhangt hoe deze regel uitwerkt. Zo kan bij de beoordeling van een beroep op het vertrouwensbeginsel de twee- of meerpartijenverhouding relevant zijn voor het al dan niet stellen van het dispositievereiste, dat inhoudt dat een partij gehandeld moet hebben op basis van het gewekte vertrouwen. Maar, die nuance van toepassing al naar gelang het rechtsgebied, speelt eveneens een rol bij wél gecodificeerde beginselen, zoals het zorgvuldigheidsbeginsel. Kortom: de vraag blijft of de Awb-wetgever de meer materiële beginselen van behoorlijk bestuur 
niet te gemakkelijk van de codificatietafel schuift? Een algemene regeling die meer materiële onderwerpen ongeregeld laat, laat veel in handen van de bijzondere wet- of regelgever. Dat bevordert de algemene aard van de wet niet.

Daarnaast kleeft er nog een gevaar aan de ruime mate waarin de Awb met procedureel recht is gevuld: een (te) grote aandacht voor procedurele regels bij de dagelijkse gebruikers van de Awb, zoals ambtenaren, rechters en wetenschappers. 'Alles wat je aandacht geeft groeit', leert een Oosterse wijsheid. De aandacht die de Awb-regels op het gebied van rechtsbescherming hebben gekregen in het algemeen, maar zeker ook in de verschillende rondes van wetsevaluatie, is zeer aanzienlijk. Michiels trekt daar, wat ons betreft terecht, de wenkbrauwen bij op: 'Als de evaluatie ertoe moet leiden de uitvoering van de wet te verbeteren, dan moet dat toch beginnen met het primaire proces van besluitvorming en niet met hoe fouten daarin kunnen worden hersteld of wat er tegen bestuurlijke en ambtelijke fouten kan worden ondernomen.' ${ }^{\text {28 }}$ De procedurele insteek van de Awb genereert vooral debat op dat procedurele vlak. Die discussie moet worden gevoerd, maar wat ons betreft is in de toekomst meer bezinning nodig op de vraag hoe het recht bij kan dragen aan een kwalitatief goed bestuur, dat het vertrouwen van de burger geniet, zonder meteen te vluchten in een regeling van het procedurele recht. ${ }^{29}$ Een algemene codificatie van het bestuursrecht moet daarom vooral ook gaan over de vraag hoe de bestuursrechtelijke verhouding (met alle variatie daarin van repeatplayer tot oneshotter) eruit moet zien. Voor die bestuursrechtelijke rechtsverhouding is bijvoorbeeld het debat over de algemene beginselen van behoorlijk bestuur, het concept van good governance en het recht op informatie in bestuurlijk verkeer van minstens zo groot belang. ${ }^{\mathbf{3 0}}$

\subsection{De Awb: vooral algemene regels?}

'De Awb is er niet voor de belangrijkste maar voor de meest algemene regels van bestuursrecht', aldus Schueler. ${ }^{\mathbf{3 1}}$ Dat algemene basisregels in de Awb thuishoren is evident. De basisregels zijn nodig om 'het systeem' uiteen te zetten en het creëren van een systeem is, zo kwam hiervoor aan de orde, een van de belangrijkste voordelen van een algemene codificatie. De organisatie van het besluitvormingsproces en de rechtsbescherming zijn daarmee onmisbare onderwerpen voor een Awb. Algemene normen bieden verder een belangrijke kapstok om samenhang te brengen in het zeer uiteenlopende materiële bestuursrecht. Het zorgvuldigheidsbeginsel van artikel 3:2 Awb vervult bijvoorbeeld die functie. De norm maakt het mogelijk om rechtspraak op zeer uiteenlopende materiële rechtsgebieden te ordenen en daartussen verbanden te leggen. Op die wijze geeft de algemene norm een impuls om zowel te harmoniseren als uit te leggen waar en waarom het materiële recht een meer specifieke invulling van de zorgvuldigheidsnorm behoeft.

De behoefte aan, of schoonheid van algemene normen zegt naar onze smaak echter nog niets over de ruimte die aan meer specifieke normen in de Awb zou moeten worden gegeven. Algemene regels kunnen de toegankelijkheid van het recht vergroten, maar doen dat niet zonder meer. Algemene regels zijn vaak wat abstract en vaag van aard en vergen een nadere invulling aan de hand van de concrete feiten, de aard van de rechtsbetrekking en de aard van het materiële recht. De interpretatie van de algemene norm in een concreet geval is veelal met onzekerheid omgeven. ${ }^{\mathbf{3 2}}$ Algemene normen kunnen dan een belangrijke ordenende functie hebben, sturend zijn zij zelden. Voor een harmoniserende (en dus) sturende, goed toegankelijke en daarmee rechtszekerheid biedende 
Algemene wet bestuursrecht zijn ook meer specifieke normen noodzakelijk. Dat lijkt de Awb-wetgever ook aan te voelen. Wat betreft de regeling van bestuursbevoegdheden zien we dat de Awb-wetgever steeds met nieuwe, specifiekere voorstellen is gekomen die de Awb aanzienlijk uitbreiden. In het kader van de derde tranche biedt de regeling van de subsidie met haar 60 artikelen daarvan een goede illustratie. Deze trend van een ambitieuze wetgever die 'nieuwe onderwerpen' steeds preciezer bij de kop pakt, is na de derde tranche zeker niet gestopt, zo illustreren titel 4.4 inzake bestuursrechtelijke geldschulden en de (nog in werking te treden en in omvang veel bescheidener) titel 4.5 inzake nadeelcompensatie. De nagestreefde doelstellingen van de Awb-wetgever lijken daarmee te verschuiven: van codificering naar harmonisering en expliciete modificering c.q. sturing.

Wij zijn daarover niet op voorhand negatief. Het verzamelen van specifieke normen in de Awb biedt de niet-ingewijden in het bestuursrecht de mogelijkheid om eenvoudiger de rechtspositie te bepalen. Deze meer precieze rechten en aanspraken zijn bovendien voor burgers gemakkelijker in rechte af te dwingen. Vanuit dat oogpunt is de subsidietitel een voorbeeld van een grotendeels geslaagd project: op een beleidsterrein waar vele burgers in hun leven mee te maken krijgen, is orde, (meer) transparantie en rechtszekerheid ontstaan. Datzelfde kan worden gesteld over de titel over handhaving. Door concrete normen te formuleren waaraan een last onder dwangsom of last onder bestuursdwang moet voldoen, kan een ieder nagaan of de opgelegde sanctie aan de wettelijke eisen voldoet. Verfijning en regeling op detailniveau kan dus de rechtszekerheid vergroten. Maar, er komt een moment dat die verfijning ten koste gaat van de coherentie, de inzichtelijkheid en daarmee de toegankelijkheid van het bestuursrecht. Een goede ordening in hoofdstukken en titels of boeken, zoals bij het BW, is dan onontbeerlijk. Een logica van de ordening van het huidige hoofdstuk 4 Awb bestaat, maar is niet evident, nu de bepalingen niet zonder meer zijn geordend langs het principe van algemeen naar bijzonder. Uit ervaring weten wij bijvoorbeeld dat de meeste studenten hard zoeken naar een regeling van de beleidsregel, omdat zij die regeling niet meer in dat hoofdstuk verwachten.

Daarnaast bestaat het nadeel dat een regeling te specifiek wordt vormgegeven, waardoor het toepassingsbereik van de wettelijke regeling te zeer wordt beperkt. Beziet men bijvoorbeeld de aard van de normen die met betrekking tot advisering in Afdeling 3.3 Awb zijn gecodificeerd, dan is niet duidelijk waarom die normen alleen zouden gelden in het geval een persoon of college bij of krachtens wettelijk voorschrift met de adviestaak is belast. Zo geeft de Awbafdeling rechtszekerheid als het gaat om adviestermijnen en bevat deze verschillende bepalingen die de zorgvuldigheid van het onderzoek vergroten. De naam van de adviseur maakt het mogelijk diens deskundigheid te evalueren en de vergewisplicht zet het bestuur aan om kritisch te kijken naar het logische verband tussen de feitelijke bevindingen en de gevraagde metabeoordeling. Deze normen, die op de inhoudelijke kwaliteit sturen, zijn bij elk deskundigenadvies van belang. Echter, door het toepassingsbereik in artikel 3:5 Awb zo nauw tot de wettelijke adviseur te beperken, laat de wettelijke regeling de rechtspraktijk onnodig met lege handen achter. Natuurlijk schuilt er een idee achter deze 'smalle' regeling: het moet voor bestuursorganen aantrekkelijk zijn om op laagdrempelige en eenvoudige wijze advies in te winnen. Maar moeten daarvoor vrij essentiële zorgvuldigheidsnormen worden opgeofferd? Dan wint de kwaliteit van de besluitvorming weinig bij het inwinnen van een informeel advies. Gedetailleerde regels bieden vaak belangrijke waarborgen; voor het gevaar dat die onderuit worden geschoffeld door het toepassingsbereik te beperken, dienen 
we steeds alert te zijn.

Op dat vlak zien we een belangrijke taak voor de Awb-wetgever in de komende jaren: niet alleen nieuwe onderwerpen aan de Awb toevoegen, maar ook bezien of het algemene bestuursrecht een kwaliteitsimpuls krijgt indien specifieke regelingen een breder toepassingsbereik krijgen, worden veralgemeniseerd of dienen als basis voor een brede algemene regeling. Zo zouden de ervaringen die zijn opgedaan met het subsidieplafond kunnen dienen als basis voor enkele algemene regels voor de verdeling van 'schaarse rechten'33 en kunnen de regels die zijn opgesteld over de intrekking van subsidiebeschikkingen uitgangspunt vormen voor de reeds lang bepleitte algemene regeling voor de intrekking van beschikkingen. 34

Ten slotte leidt deze overdenking nog tot de vraag wat regels nu daadwerkelijk algemeen maakt. Is het algemene bestuursrecht wel echt algemeen, of noemen we het algemeen omdat het in de Awb staat? Over de omvang van de afwijkingen van de Awb in bijzondere regelgeving is niet zo veel bekend. De fiscale wetgever doet in ieder geval vaak de eigen zin. Bestuursrechtjuristen roepen dan al snel in fiscalibus wordt weer iets "bijzonders" geregeld'. ${ }^{35}$ Maar is dat eigenlijk wel zo, bijvoorbeeld gemeten aan het aantal besluiten dat wordt genomen op grond van die bijzondere wetgeving (om nog niet te spreken over de impact daarvan op het leven van burgers)? Hoe vaak is de uitzondering eigenlijk de regel, zoals bij geldschulden het geval lijkt te zijn, nu deze regeling in voor burgers zeer belangrijke formele wetgeving zoals de Awir goeddeels buiten spel is gezet? ${ }^{36}$ Dat zou een mooi thema zijn voor een toekomstige wetsevaluatie. Nader onderzoek kan dan inzichtelijk maken van welk type normen uit de Awb relatief veelvuldig in bijzondere regelgeving wordt afgeweken en waarom. Dat kan enerzijds tot de conclusie leiden dat, bij nader inzien, de voorziening zich er helemaal niet zo voor leende om in een algemene wet te worden geregeld. Anderzijds kan de afwijking ook wat zeggen over de kwaliteit van de Awb-norm voor de uitvoeringspraktijk. Hoe sterker de Awb-norm essentiële onderwerpen voor de uitvoeringspraktijk ongeregeld laat, hoe veelvuldiger aanvulling nodig zal blijken te zijn. Met een dergelijk zelfinzicht zal de Awb-wetgever ongetwijfeld zijn voordeel kunnen doen.

Als de wetgever zich dan toch bezint op het belang van de Awb-bepaling voor de uitvoeringspraktijk, kan hij wellicht tegelijkertijd tot de conclusie komen dat bepaalde wetsartikelen ook wel uit de Awb kunnen worden geschrapt. Zo hebben we al afscheid genomen van de bepalingen over de Friese taal.37 Voor een dergelijk afscheid nomineren wij hier bijvoorbeeld ook Afdeling 4.2.8 Awb (Per boekjaar verstrekte subsidies aan rechtspersonen) en Afdeling 7.3 Awb (Bijzondere bepalingen over administratief beroep). De bepalingen uit de subsidieafdeling zijn zo ingewikkeld dat niemand ze snapt en administratief beroep is dermate uitzonderlijk geworden dat deze bepalingen zich niet langer lenen voor een voorziening in de algemene wet. Kritische vragen kunnen ook worden gesteld bij de regeling over samenhangende besluiten ${ }^{\mathbf{3}}$ en, op grond van de bijdrage van Broeksteeg, bij de titel over het toezicht op bestuursorganen. Natuurlijk, we kunnen alles ook in de Awb laten staan, maar een overcomplete regeling komt uiteindelijk de toegankelijkheid van de algemene wet niet ten goede. En juist die toegankelijkheid zagen we toch als een van de grote voordelen van een algemene regeling van het bestuursrecht.

\subsection{Lessen uit de algemene codificatie in het BW}

Het bestuursrecht is het laatste van de drie grote rechtsgebieden dat een 
algemene codificatie heeft gekregen; het burgerlijk recht en het strafrecht gingen het bestuursrecht voor. Het valt op dat deze drie codificaties verschillen naar reikwijdte. Het burgerlijk recht en het strafrecht kennen codificaties die zowel het materiële recht als het procesrecht omvatten, en die bovendien een zekere volledigheid pretenderen. Die pretentie is in ieder geval waargemaakt voor het procesrecht. In samenhang met de Wet op de Rechterlijke Organisatie bieden de wetboeken van Burgerlijke rechtsvordering en Strafvordering een volledige regeling van het procesrecht. Dat geldt voor het bestuursprocesrecht overigens niet anders: de Awb kent een volledige regeling voor het bestuursproces. Dat wellicht onderdelen van dat bestuursprocesrecht nog enige precisering of ontwikkeling behoeven, zoals het bewijsrecht en de nieuwe regeling inzake de verzoekschriftprocedure voor schadekwesties, doet daaraan niet veel af. Het resultaat is in ieder geval duidelijkheid over de te volgen (gerechtelijke) procedures en de daarbij geldende regels. Dat is niets nieuws; zulke duidelijkheid is een minimumvereiste voor de toegankelijkheid van het recht voor de burger. Zelfs common-law-stelsels kennen daarom codificaties van burgerlijk procesrecht. 39

Voor het materiële recht is het beeld diffuser. Wij constateerden dat de Awb op materiële onderwerpen nog het nodige liet liggen. Het is (uiteraard) geen vanzelfsprekendheid dat codificaties beperkt blijven tot procesrechtelijke punten. Het lijkt erop dat het Burgerlijk Wetboek de centrale plek is en was voor de regeling van de privaatrechtelijke rechtsverhoudingen, ongeacht of zij vanouds bestonden, of voortkomen uit nieuwe gedachten. Er moeten goede redenen zijn om elders opgenomen regelingen van privaatrechtelijke rechtsverhoudingen buiten het BW te blijven houden. Om die reden is, anders dan bijvoorbeeld in België, ook het handelsrecht in het BW opgenomen. ${ }^{40}$ Wanneer privaatrechtelijke bepalingen desondanks toch elders worden gehandhaafd, wordt ten minste gestreefd naar stroomlijning met het BW. ${ }^{\mathbf{4 1}} \mathrm{Met}$ andere woorden: het BW is hèt kader voor het materiële recht. Het zuigt elders nog bestaand materieel burgerlijk recht naar zich toe. Dat is niet het geval bij het materiële strafrecht en het materiële bestuursrecht. Ook hier kan wel een algemeen deel en een bijzonder deel worden onderscheiden, maar van een leegtrekken door de algemene wetboeken is geen sprake. Voor daadwerkelijk bijzondere delen is dat leegtrekken op grond van variatie van regels, de omvang daarvan en/of het gebrek aan algemene relevantie waarschijnlijk ook niet mogelijk. Wij zijn er echter bepaald niet van overtuigd dat er niet meer gemeenschappelijke materiële regels uit bijzondere delen van het bestuursrecht afgeleid kunnen worden, om die vervolgens in de Awb te codificeren. De wetgever zou in dat kader kunnen bezien welke fundamentele elementen bepalend zijn voor de rechtsverhouding tussen bestuur en burger en of deze thans regeling in de Awb hebben gevonden. Waarom zou bijvoorbeeld voor bestuursrechtelijke verhoudingen omtrent openbaarheid van bestuur nog steeds een aparte wet nodig zijn? Waarom zou het veel bediscussieerde 'naming and shaming' niet netjes als (bijkomende) sanctie in hoofdstuk 5 Awb kunnen worden opgenomen? Anderzijds mogen wij er ook niet aan voorbij gaan dat de codificatie van het burgerlijk recht al enige eeuwen aan de gang is en de laatste grote codificatie van het BW decennia in beslag heeft genomen. In zoverre heeft het bestuursrecht nog een weg te gaan, waarbij wat ons betreft de Awb-wetgever een hoger ambitieniveau mag hebben voor de codificatie van meer materiële normen. 
De voordelen van een codificatie van algemeen bestuursrecht zijn al verschillende malen belicht. Tot de belangrijkste voordelen behoren de vergroting van de toegankelijkheid van het recht en de systematiserende werking die van een algemeen raamwerk uitgaat. Deze voordelen heeft de Awb in zijn huidige vorm grotendeels, maar nog niet geheel, weten te realiseren. Zo ontbreken nog enkele onderwerpen die wij essentieel achten voor de vraag hoe de bestuursrechtelijke rechtsbetrekking tussen bestuur en burger eruit dient te zien: de meer materiële algemene beginselen van behoorlijk bestuur, het concept van good governance en het recht op informatie in bestuurlijk verkeer. In deze derde paragraaf hebben we de voordelen van codificatie van procedurele regels en algemene basisregels belicht, maar daarnaast ook benoemd waarom een dergelijke codificatie op hoofdlijnen onvoldoende is. Door meer materiële keuzes uit de weg te gaan, laat de Awb-wetgever soms teveel over aan de bijzondere wetgever, wat het algemene en sturende karakter van de Awb teniet doet. Ten aanzien van zeer specifieke normen in de Awb hebben we willen belichten dat zij enerzijds rechtszekerheid brengen, anderzijds dat hun toepassingsbereik soms zonder overtuigende redenen te beperkt is, waarmee de normering willekeurig kan worden.

De Awb-wetgever deden wij enkele suggesties voor de toekomst. Ten eerste, bezie of fundamentele elementen van de rechtsbetrekking tussen burger en bestuur voldoende door de Awb worden genormeerd. Ten tweede, voeg niet alleen nieuwe onderwerpen aan de Awb toe, maar bezie ook of het algemene bestuursrecht een kwaliteitsimpuls krijgt indien vrij smalle regelingen een breder toepassingsbereik krijgen of worden veralgemeniseerd. Ten derde, vergaar meer kennis over de mate van afwijking van Awb-normen in bijzondere regelgeving en de redenen daarvoor. Meer in het algemeen bevelen wij aan voldoende belangstelling te hebben voor de waarde van Awb-normen voor de rechtspraktijk. De wetgevingscapaciteit is beperkt en die zou moeten worden ingezet waar de Algemene wet bestuursrecht werkelijk van algemeen (en niet enkel theoretisch) belang kan zijn.

\section{Bezinning: de betekenis van de Awb voor een Europese algemene codificatie van bestuursrecht}

\subsection{Inleiding}

Vanuit een internationale bril bezien maakte de codificatie van het algemeen bestuursrecht in de Awb deel uit van de derde bestuursrechtelijke 'codificatiegolf' in Europa. ${ }^{42}$ Inmiddels is een vierde golf in beweging. In een door het Europees Parlement aangenomen resolutie wordt de Europese Commissie opgeroepen om te komen tot een verordening over een Europese wet bestuursprocesrecht (hierna veelal: Ewb). 43 Deze verordening zou moeten worden gebaseerd op artikel $298 \mathrm{VwEU}$, op grond waarvan de instellingen, organen en instanties van de Unie bij de vervulling van hun taken steunen op een open, doeltreffend en onafhankelijk Europees 'bestuur'44 en op grond waarvan het Europees Parlement en de Raad volgens de gewone wetgevingsprocedure bij verordeningen de bepalingen daartoe vaststellen. In het licht van deze resolutie rijst de vraag of wij, op grond van de Nederlandse codificatie-ervaringen met de Awb, aanbevelingen kunnen geven voor de 'Europese Awb'. Alvorens daarop in te gaan, schetsen wij hieronder kort de contouren van de beoogde Europese wet bestuursprocesrecht waarvoor het Europees Parlement 'gedetailleerde aanbevelingen' heeft geformuleerd. 
Het centrale doel van de beoogde verordening is het waarborgen van het recht op behoorlijk bestuur door middel van een open, efficiënte en onafhankelijke administratie op de grondslag van een Europese wet bestuursprocesrecht. In het bijzonder moet de verordening de grondbeginselen van goed bestuur codificeren en de door de EU-administratie te volgen procedure regelen voor behandeling van individuele gevallen, waarbij een natuurlijk persoon of rechtspersoon partij is en andere situaties waarbij een persoon rechtstreeks of persoonlijk in contact komt met de administratie van de Unie. ${ }^{45}$ De reikwijdte van de beoogde verordening is daarmee beperkt tot het zogeheten 'rechtstreekse bestuur', dus tot het contact van burgers met de instellingen van de Unie. ${ }^{\mathbf{4 6}}$ De toepassing van Unierecht door nationale instanties (bestuursorganen) blijft hierdoor, in beginsel, $\mathbf{4 7}$ buiten het bereik van deze verordening.

De verordening moet een universeel geheel van beginselen omvatten en een procedure regelen die als de minimis-regel moet gelden wanneer geen lex specialis bestaat. Verder mogen de waarborgen in sectorale instrumenten niet minder bescherming bieden dan de waarborgen in deze verordening. ${ }^{48}$ Voor zover dus wel een lex specialis bestaat, mag die niet onder het beschermingsniveau van de Europese wet bestuursprocesrecht duiken.

Het Europees Parlement verlangt de codificatie van een groot aantal beginselen waaraan de administratie is gebonden, waaronder de ons minder vertrouwde beginselen van continuïteit, transparantie en dienstbaarheid. Verder moet de verordening diverse regels bevatten die gelden voor administratieve besluiten. In dat verband formuleert het Europees Parlement een tiental aanbevelingen, waaronder de verplichting tot schriftelijke ontvangstbevestiging van verzoeken om een individueel besluit, het recht op toegang tot het eigen dossier, de verplichting tot het nemen van administratieve besluiten binnen een redelijke termijn en de verplichting tot motivering van deze besluiten. Tot slot moet de verordening de mogelijkheid bieden om administratieve besluiten te herzien of te corrigeren.

Bovenstaande schets maakt duidelijk dat de beoogde reikwijdte van de Europese wet bestuursprocesrecht niet te beperkt moet worden opgevat. Dit bestuursprocesrecht omvat in elk geval niet alleen de rechtsbescherming nadat een besluit is genomen, maar eerst en vooral het besluitvormingsrecht. Tegelijk is de resolutie sterk vanuit het perspectief van de (individuele) Europese burger geformuleerd. ${ }^{49}$ Daarmee is overigens nog niet gezegd dat de bepalingen in de verordening uiteindelijk beperkt zullen blijven tot individuele besluitvorming. Zo zijn vanuit het ReNEUAL Research Network on European Administrative $L a w$ vier centrale onderwerpen geïdentificeerd die een plek zouden kunnen krijgen in een Europese Awb: individuele besluitvorming ('unilateral decision making'), normstelling ('rulemaking'), overheidscontracten en informatiebeheer (gegevensbescherming en toegang tot documenten). ${ }^{50}$

\subsection{Lessen uit de Awb voor Europa?}

Craig schrijft dat een Ewb 'can enhance the clarity of, and facilitate access, to the law; increase the coherence of principles and procedures; set up default procedures to fill gaps in existing law; and establish the functions of administrative procedure'.$^{\mathbf{5 1}}$ Dat sluit aan op de eerder in paragraaf 3.2 belichte voordelen van een algemene codificatie. Maar er is niet alleen op deze algemene voordelen van codificatie te wijzen. In zijn resolutie overweegt het Europees Parlement expliciet dat een aantal kernbeginselen van goed bestuur inmiddels 
ruime aanvaarding heeft gevonden in de lidstaten. ${ }^{\mathbf{5 2}}$ Deze aansluiting bij de nationale bestuursrechtelijke tradities roept de vraag op welke lessen het codificatieproces van de Awb bevat voor de Europese Awb. Daarbij zoeken we in het bijzonder aansluiting bij de bevindingen over de derde tranche van de Awb. Allereerst laat de Awb zien dat een algemene wet bestuursrecht soms veranderingen teweegbrengt, maar tegelijkertijd stuit op een behoudende rechtspraktijk (paragraaf 2.2). Dit brengt mee dat de verwachtingen over het sturend vermogen van een codificatie van algemeen bestuursrecht niet te hoog gespannen moeten zijn. Nationale en Europese bestuursorganen kunnen de toepassing van wettelijke bepalingen 'kneden', met name wanneer deze bepalingen tamelijk abstract zijn geformuleerd. Dit hoeft niet bezwaarlijk te zijn, aangezien de bepalingen hierdoor juist toekomstbestendig kunnen zijn en bijvoorbeeld kunnen inspelen op technologische ontwikkelingen, zoals toenemend elektronisch verkeer met en tussen bestuursorganen. Tegelijk kan de betekenis van een algemene wet bestuursrecht irrelevant worden wanneer hiervan te weinig (materiële) sturing uitgaat. $\mathrm{Nu}$ de Europese Awb veel nadruk legt op algemene beginselen dreigt hier een gevaar. Dat gevaar is echter relatief wanneer men bedenkt dat het Hof van Justitie regelmatig op grond van algemene beginselen gedetailleerde materiële verplichtingen voor het bestuur vaststelt.

Het codificatieproces van de Awb laat verder zien dat telkens wanneer de wetgever probeert een rechtsfiguur te definiëren en te codificeren, complicaties ontstaan over de precieze reikwijdte van de definitie. Codificatie leidt in die zin niet alleen tot vereenvoudiging maar mogelijk ook tot complicering (paragraaf 2.3). Voor de Europese Awb is een belangrijk afbakeningsvraagstuk de definitie van het bestuursoptreden waarop deze verordening betrekking heeft. Wanneer de reikwijdte van de verordening beperkt is tot het zogeheten 'rechtstreekse bestuur' (zoals is beoogd) ${ }^{\mathbf{5 3}}$, rijst onmiddellijk de vraag welk bestuursoptreden nog wel en welk optreden niet meer tot dit rechtstreekse bestuur behoort. Wat is bijvoorbeeld de status van gedeeld of gemengd bestuur in het kader van de Ewb? 54

Een derde les van het Nederlandse codificatieproces is dat codificatie deels divergentie met vergelijkbare rechtsfiguren veroorzaakt (paragraaf 2.4). Anders gezegd: als een rechtsfiguur eenmaal algemeen is gecodificeerd ziet de bijzondere wetgever geregeld reden om die rechtsfiguur net even anders te regelen dan in die algemene regeling. De poging dit verschijnsel tegen te gaan met materiële definities blijkt niet steeds even succesvol, zo laten de ervaringen met de derde tranche van de Awb duidelijk zien. Het Europees Parlement heeft in dit verband de belangwekkende aanbeveling gedaan dat de Europese Awb een de minimis-karakter moet hebben, zodat sectorale regelgeving hiervan niet mag afwijken. De Nederlandse Awb kent een dergelijk karakter niet; er is geen hiërarchie tussen wetten in formele zin. $\mathbf{5 5}$

Tot slot is van belang dat het Europees Parlement heeft verzocht om de vaststelling van een Europese wet bestuursprocesrecht. Hoewel dit bestuursprocesrecht juist ook procedurele bepalingen over de besluitvormingsfase moet bevatten, lijken meer materiële normen buiten het bereik van de Europese Awb te blijven, zij het dat de Europese Awb zal zijn geënt op een aantal fundamentele beginselen. Terwijl de aanbevelingen van het Europees Parlement zich dus lijken te beperken tot basisregels, laten de voorstellen van het ReNEUAL Research Network on European Administrative $L a w$ juist een grotere mate van differentiatie zien met afzonderlijke regels voor individuele besluitvorming, algemene normstelling, overheidscontracten en informatiebeheer (gegevensbescherming en toegang tot documenten). Een 
bredere benadering van de Europese Awb is dus zeker denkbaar.

We zien hier een ontwikkeling die vergelijkbaar is met die in Nederland. De codificatie van algemeen bestuursrecht vertrekt vanuit de basisgedachte dat basisregels gecodificeerd dienen te worden, maar al snel strekt de ambitie verder en worden de regels meer bijzonder en gedetailleerd. In de derde paragraaf hebben we die ontwikkeling, hoewel in hoofdzaak positief, uiteenlopend gewaardeerd. Een fixatie op regels van procesrecht moet worden voorkomen. Basisregels zijn noodzakelijk om de met codificatie gewenste ordening en systematisering te realiseren. Aan de andere kant kan van meer specifieke bepalingen een sterkere sturende en daarmee werkelijk harmoniserende werking uitgaan.

\subsection{Een boemerang-effect?}

In zijn resolutie overweegt het Europees Parlement ook dat een Europese wet bestuursprocesrecht een spontane convergentie in het nationale bestuursrecht in de hand kan werken ten aanzien van algemene procedurele beginselen en grondrechten van burgers jegens de overheid, waarmee ook het integratieproces kan worden versterkt. ${ }^{\mathbf{6}}$ Zal het Awb-project iets meenemen van de huidige ontwikkelingen op Europees niveau?

Opvallend aan de benadering van het Europees Parlement is de grote aandacht voor codificatie van beginselen. Wij stelden hiervoor al de vraag of sommige van die beginselen in het nationale bestuursrecht wel voldoende aandacht hebben gekregen. Zo wordt de aanbeveling gedaan om het dienstbaarheidsbeginsel in te voeren, inhoudende dat het bestuur moet proberen de burger te begeleiden, te helpen en van dienst te zijn, te ondersteunen en vriendelijk en beleefd te bejegenen. Dit soort behoorlijkheidsnormen worden in de Nederlandse discussie nog weinig als juridisch bindende normen benaderd. De juridische discussie over codificatie van het transparantiebeginsel is in Nederland verder gevorderd.57 Zonder direct codificatie van dit soort beginselen te willen bepleiten, kunnen we vaststellen dat deze Europese catalogus van beginselen in elk geval stof tot nadenken geeft voor de Awb-wetgever, de literatuur en de rechtspraktijk.

Verder is opvallend dat in de Europese Awb veel aandacht wordt gevraagd voor informatiebeheer, informatie-uitwisseling en informatieverschaffing. De toegenomen aandacht voor (openbaarheid van) informatie werpt (opnieuw) de vraag op of een regeling inzake informatie eigenlijk niet thuishoort in de Awb in plaats van de Wet openbaarheid van bestuur.58 Op Europees niveau ziet men kennelijk wel de noodzaak om dit essentiële element in de rechtsbetrekking tussen burger en bestuur direct in een algemene bestuursrechtelijke codificatie neer te leggen.

Tot slot geven de ontwikkelingen op Europees niveau, in het bijzonder de voorstellen van het ReNEUAL Research Network on European Administrative Law, aanleiding om de reikwijdte van 'onze' algemene regels van bestuursrecht in de Awb nog eens kritisch te bezien. De Europese voorstellen gaan zelfs 'het besluit voorbij'59 door te voorzien in afzonderlijke regels voor overheidscontracten naast eenzijdige besluitvorming. Zonder direct het loslaten van het besluitbegrip voor de Awb te willen bepleiten, is er - zoals wij in paragraaf 3.4 al opmerkten - minstens aanleiding om (opnieuw) te onderzoeken in hoeverre 'smalle' regelingen in de Awb, bijvoorbeeld de regeling over wijziging en intrekking van subsidiebeschikkingen, zich lenen voor een breder toepassingsbereik. 


\subsection{Slotopmerking}

De Nederlandse ervaringen met codificatie van algemeen bestuursrecht én met de gevolgen daarvan, bieden enkele belangrijke aandachtspunten voor het project van een Europese wet bestuursrecht. Allereerst dient de Europese wetgever te beseffen dat de rechtspraktijk ook na codificatie haar eigen weg wel weet te vinden en soms zelfs bewust zal opzoeken. Verwachtingen over uniformering van bestuursrecht moeten daarom niet te hoog gespannen zijn. Verder laat de Awb zien dat met name procesrecht zich gemakkelijk laat codificeren, maar dat het materiële bestuursrecht hierdoor soms te gemakkelijk buiten het bereik van codificatiepogingen blijft. Juist nu de Europese wet bestuursprocesrecht zich nog in de ontwerpfase bevindt, dient de Europese wetgever in dit stadium bewuste keuzes te maken.

Als de Europese wet bestuursrecht eenmaal het licht ziet, valt te bezien welke bottom up beïnvloeding vervolgens zal uitgaan van de nationale bestuursrechtelijke codificaties. Het ligt voor de hand dat het Hof van Justitie bij de invulling van de algemene beginselen aansluiting zal zoeken bij de rechtsordes van de lidstaten. Daarbij ligt de nadruk echter wel vaak op de rechtsordes van de grote lidstaten. Voor de kleinere lidstaten is daarom van belang dat zij juist in dit stadium waarin de Ewb nog in ontwikkeling is, hun gedachten, ervaringen en wensen nadrukkelijker onder de aandacht te brengen ten behoeve van de rechtsontwikkeling. Omgekeerd zal het Europese project zeker invloed hebben op de Awb, via gedeelde besluitvorming of via spontane harmonisatie. Dit kan een extra reden zijn om het materiële bestuursrecht nadrukkelijker een plek te geven in de Awb; juist daarin kan de Awb op termijn meerwaarde hebben ten opzichte van de Ewb dat zich - om begrijpelijke codificatieredenen - vooral richt op procedurele aspecten. Vele codificatiegolven zullen nog moeten volgen voordat de Awb volledig wordt overspoeld door een Europese Awb die het handelen van alle (Europese en nationale) bestuursorganen normeert.

\section{Slotbeschouwing}

De in deze NALL-special verrichte terugblik op de derde tranche van de Awb vormde aanleiding om te bezien of daaruit algemene codificatielessen kunnen worden getrokken. Een van onze hoofdbevingen is dat van de in de Awb opgenomen normen lang niet altijd een sturende werking uitgaat. Veel algemene regels systematiseren en ordenen, maar sturen in beperkte mate de rechtspraktijk. Bovendien kiest de praktijk regelmatig bewust voor afwijking van de algemene regeling. Op die wijze blijft de harmoniserende werking die de Awb zou kunnen hebben onderbenut. Die kanttekening maakt ons niet minder enthousiast voor een algemene codificatie van bestuursrecht. Alleen al de vastlegging van regels in de Awb heeft tot gevolg dat de aandacht voor en discussie over regels van bestuursrecht enorm is vergroot. Mede dankzij de Awb zijn er bijvoorbeeld leerstukken ontstaan op voor burgers belangrijke onderwerpen, zoals de bestuurlijke toezichtstaak en de subsidies. De Awb uniformeert het bestuursrechtelijke taalgebruik en ordent de besluitvormingsketen, waardoor juristen vanuit verschillende expertises gemakkelijk met elkaar kunnen communiceren, debatteren en zaken doen. Zo vormt de Awb een belangrijke katalysator die bijdraagt aan de bestuursrechtelijke rechtsontwikkeling.

Bovengenoemd enthousiasme laat onverlet dat wij (zoals velen) nog wel een wensenlijstje hebben voor toekomstige aanpassingen in de Awb. Bezien wij de 
verschillende potentieel aan codificatie klevende voordelen, dan menen wij dat op de elementen 'kenbaarheid', 'overtuigingskracht' en 'kwaliteit' nog een slag te maken is. De kenbaarheid wordt nu nog onvoldoende gerealiseerd doordat belangrijke elementen van de rechtsbetrekking tussen burger en bestuur buiten de Awb zijn gebleven. In het kader van de overtuigingskracht hebben we belicht dat het toepassingsbereik van sommige normen in de Awb smal is, zonder dat daar (nog langer) een overtuigende reden bestaat. Wij hebben vooral gepleit voor meer materiële normen en beginselen in de Awb; een kwalitatief goede regeling van algemeen bestuursrecht heeft in de meer volwassen fase van haar bestaan juist op dat vlak ambities, temeer als Nederland met haar Awb een gidsland in Europa wil zijn.

\section{Noten}

1 Tot 1 januari 2013 bevatte artikel 11:1 Awb een evaluatieplicht, die inhield dat de Ministers van Justitie en Binnenlandse Zaken om de vijf jaar aan de StatenGeneraal een verslag over de toepassingswijze van de Awb dienden te sturen. Zie nader F.C.M.A. Michiels, 'Het evalueren van de Awb: een voortdurend proces', in: T. Barkhuysen e.a. (red.), Bestuursrecht harmoniseren: 15 jaar Awb, Den Haag: Boom Juridische uitgevers 2010, p. 41-55.

2 Zie F.A.M. Stroink e.a. (red.), Vijf jaar JB en Awb, Den Haag: Sdu 1999; F.A.M. Stroink e.a. (red.), Tien jaar JB en Awb, Den Haag: Sdu 2004; T. Barkhuysen, W. den Ouden en J.E.M Polak (red.), Bestuursrecht harmoniseren: 15jaar Awb, Den Haag: Boom Juridische uitgevers 2010, www.nall.nl/pagina/bibliotheek.

3 Zie meest recent Resolutie van het Europees Parlement van 15 januari 2013 met aanbevelingen aan de Commissie betreffende het bestuursprocesrecht van de Europese Unie, 2012/2024(INL), http://www.europarl.europa.eu/oeil/popups/ficheprocedure.do? reference $=2012 / 2024($ INI $) \& \mathrm{l}=\mathrm{en}$.

4 De vijf bijdragen betreffen: Hansko Broeksteeg, 'De Awb als constant van het bestuurlijk toezicht', NALL 2013, DOI: 10.5553/NALL/.ooo014; Rianne Jacobs \& Willemien den Ouden, 'Wat was, werd en wordt belangrijk in het algemene subsidierecht?', NALL januari 2014, DOI: 10.5553/NALL/.000017; Lex Michiels, 'Bestuurlijke handhaving sinds de derde tranche Awb', NALL december 2013, DOI: 10.5553/NALL/.ooo015; Rolf Ortlep, 'Bekendmaking besluit op een andere geschikte wijze', NALL december 2013, DOI:

10.5553/NALL/.ooo016; Albertjan Tollenaar, 'Het succes van de codificatie van de beleidsregel in de Awb', NALL januari 2014, DOI: 10.5553/NALL/.000018.

5 Vergelijk A.J. Bok e.a., Nieuw bestuursrecht: Derde tranche algemene wet bestuursrecht, Nijmegen: Ars Aequi Libri 1997.

6 J. de Ridder en R.H.C. Kemkers, 'Inertie en aanpassing, de implementatie van artikel 19 lid 2 WRO', Beleidswetenschap 2002, p. 236-258.

7 Tollenaar 2014

8 Broeksteeg 2013. 
9 KB 12 juli 2012, Stb. 2012, 318.

10 Ortlep 2013.

11 Michiels 2013.

12 Denk aan de verschillende leerstoelen die toezicht en handhaving als onderwerp hebben, de oprichting van het Tijdschrift voor Toezicht en VIDE, de vereniging voor toezichthouders, inspecteurs, handhavers en evaluatoren.

13 Jacobs \& Den Ouden 2014.

14 Zie in dat verband bijv. ABRvS 11 december 2013, ECLI:NL:RVS:2013:2323.

15 CRvB 12 maart 2008, $A B$ 2008/221, m.nt. Tollenaar.

16 Michiels 2013.

$\mathbf{1 7}$ Vergelijk het aanhouden van een schip (in de volksmond bekend als 'het aan de ketting leggen') artikel 16 Schepenwet.

18 Zie daarvoor J.A. de Boer, F.C.M.A. Michiels, W. den Ouden \& P.J.J. Zoontjens, 'Anders, of toch niet? Een onderzoek naar de mogelijkheden van meer Awb-conforme onderwijswetgeving', http://www.rijksoverheid.nl/documenten-enpublicaties/rapporten/2014/02/10/onderzoek-naar-de-mogelijkheden-vanmeer-awb-conforme-onderwijswetgeving.html

19 Deze brede duiding, met inbegrip van het besluitvormingsrecht, vergemakkelijkt ook de vergelijking met de Europese Awb, die primair regels van het besluitvormingsproces beoogt te codificeren.

20 Voor de totstandkoming van deze bijdrage hebben de redacteuren eerst individueel een discussiestuk geschreven, waarin zij vanuit de eigen expertise de meer en minder geslaagde wetsartikelen uit de Awb benoemden, waarna uit de mondelinge en daarop volgende schriftelijke discussie hoofdlijnen zijn gedestilleerd. De waarderingen bleken - aanvankelijk - behoorlijk uiteenlopend.

21 M. Scheltema, 'Codificatie van het bestuursrecht', NTB 1996, p. 2-7.

22 G.A. van Poelje, Beginselen van Nederlandsch administratief recht. Deel 1, Alphen aan den Rijn: Samsom 1927, p. xvii.

23 B.J. Schueler, 'De Awb en de bijzondere delen van het bestuursrecht', in T. Barkhuysen, W. den Ouden \& J.E.M. Polak (red.), Bestuursrecht harmoniseren: 15jaar Awb, Den Haag: Boom Juridische uitgevers 2010, p.173-191.

24 Scheltema 1996, p. 5 .

25 J.E.M. Polak, 'Veranderende perspectieven van de bestuursrechter', in T. Barkhuysen, W. den Ouden \& J.E.M. Polak (red.), Bestuursrecht harmoniseren: 15jaar Awb, Den Haag: Boom Juridische uitgevers 2010, p. 97-113. 
26 Zie de $\mathrm{AB}$ annotatiereeks van Leo Damen over dit onderwerp.

27 Zie ook R.J.N. Schlössels, 'Rechtsbeginselen en de Algemene wet bestuursrecht: tevreden met een codificatie 'light”, JBplus 2012, p. 87-100.

28 Michiels 2010, p. 44.

29 Dit vormt het onderwerp van het programma 'Een prettig contact met de overheid', zie http://prettigcontactmetdeoverheid.nl/. Doel van het bestuursrecht is immers niet het zo snel mogelijk afwikkelen van (gerechtelijke) procedures, maar is gelegen in een ideaal van rechtvaardigheid of 'administrative justice'. Zie over dit concept: M. Adler (ed), Administrative justice in context, Oxford: Hart 2010; M. Herweijer e.a. (red.), Alles in één keer goed. Juridische kwaliteit van bestuurlijke besluitvorming, Deventer: Kluwer 2005.

30 Vgl. bijv. Bert Marseille \& Lynn van der Velden (red.), Vertrouwen verdient, verdiend vertrouwen. Visies op geschilbeslechting door de overheid, Den Haag 2014 en D.G.J. Sanderink, 'Het principe of 'good governance in het bestuursrecht”, Trema 2014, p. 10-15.

31 Schueler 2010, p. 173.

32 Vgl. Schueler 2010, p. 176.

33 Zie hierover Jacobs en Den Ouden, 'Eerlijk zullen wij alles delen, Ontwikkelingen in de jurisprudentie over de verdeling van de subsidiepotmeer terughoudend', JBplus 2011, p. 35 e.v. Meer terughoudend: C.J. Wolswinkel, 'Schaarse publiekrechtelijke rechten. Een algemeen leerstuk gerelativeerd', NTB 2014, 7 .

34 Zie bijv. de Commissie wetgeving algemene regels van bestuursrecht 1987, p. ii en Kamerstukken II 1999-2000, 26800 VI, nr. 7, p. 9, M.A.M. Dieperink, 'Omtrekken van een algemene regeling voor intrekken', in: De vijfde tranche, Preadviezen Jonge VAR 20O2, Den Haag, Boom Juridische uitgevers 2003, p. 55 e.v.; W. den Ouden, 'De intrekking van begunstigende beschikkingen door bestuursorganen. Eens gegeven blijft gegeven?', in: T. Barkhuysen e.a. (red.), Bestuursrecht harmoniseren: 15jaar Awb, Den Haag: Boom Juridische uitgevers 2010, p. 689-715; R. Ortlep, De aantasting van stabiele bestuursrechtelijke rechtsvaststellingen in het licht van het Unierecht, Deventer: Kluwer 2011, p. 175 e.v., 189 e.v. en p. 303 e.v.

35 Vgl. N. Verheij, 'Fiscale eigenwijsheden', NTB 2013, p. 45-47.

36 Vergelijk de Algemene wet inkomensafhankelijke regelingen (Awir), artikel 12, lid 1, art. 29 en 32: in het algemeen sluit de Awir aan op de fiscaalrechtelijke regelingen voor (invordering van) geldschulden. Volgens de website van de uitvoerende Dienst toeslagen ontvangen op dit moment ruim 6 miljoen huishoudens één of meer van deze toeslagen.

37 Stb. 2013, 382 en 515.

38 Vergelijk M.S. Beerten, Afstemming van besluiten (diss. Groningen), Den 
Haag: BJu 2004.

39 Zie nader C.H. van Rhee, 'De codificatie van het Burgerlijk Procesrecht in de Verenigde Staten van Amerika', in: J.M. van Buren-Dee e. a. (red.), Privaatrecht en Gros. Opstellen aangeboden aan Prof.mr. F. Willem Grosheide, Antwerpen/Groningen: 1999, p. 333-342.

40 Vgl. D. Heirbaut, Codificatie van het burgerlijk recht in Belgie en Nederland, parallel lives?, Gent 2010, https://biblio.ugent.be/input/download? func $=$ downloadFile $\&$ recordOId $=1048832 \&$ fileOId $=1048838$.

41 Kamerbrief van de ministers van Veiligheid en Justitie en van Economische Zaken, Landbouw en Innovatie d.d. 22 november 2011 inzake stroomlijning Burgerlijk Wetboek en consumentenbescherming, Kamerstukken I 2010/11, 31 374, nr. S.

42 Aldus J. Ziller, 'Is a law of administrative procedure for the Union institutions necessary? Introductory remarks and prospects', Brussel: Europees Parlement 2011, p. 8-9. De eerste golf dateert uit de jaren twintig van de vorige eeuw (Oostenrijk, Polen), de tweede golf uit de jaren zeventig (Duitsland, Luxemburg) en de derde golf vangt aan halverwege de jaren tachtig (Italië, Portugal, Denemarken).

43 Resolutie van het Europees Parlement van 15 januari 2013 met aanbevelingen aan de Commissie betreffende het bestuursprocesrecht van de Europese Unie (2012/2024(INI)). Vergelijk P. Craig, 'A General Law on Administrative Procedure, Legislative Competence and Judicial Competence', EPL 2013, p. 503-524. Zie eerder J.H. Jans, 'Naar een Europese Awb?', in T. Barkhuysen e.a. (red.), Bestuursrecht harmoniseren: 15 jaar Awb, Den Haag: Boom Juridische uitgevers 2010, p. 609-626; A.C.M. Meuwese, Y.E. Schuurmans \& W.J.M. Voermans, 'Towards a European Administrative Procedure Act', REALaw 2009, p. 3-35.

44 Onder verwijzing naar de Engelse tekstversie ('administration') stelt Meuwese dat de Nederlandse vertaling 'ambtenarenapparaat' in art. 298 VwEU te beperkt is, anders dan bijvoorbeeld de term 'bestuur'. Zie A.C.M. Meuwese, 'Het Europees parlement op de bres voor een 'Europese Awb”, RegelMaat 20132, p. 135 .

\section{Aanbeveling 1.}

46 Overweging $\mathrm{P}$ en aanbeveling 1.

$47 \mathrm{Al}$ ligt voor de hand dat de verordening op den duur wel invloed zal hebben op het nationale bestuursrecht, bijvoorbeeld via het proces van vrijwillige adoptie. Zie daarover expliciet overweging $S$ van de resolutie.

48 Aanbeveling 2.

49 Vgl. Meuwese 2013, p. 137.

50 Ziller 2011, p. 18-21. 
51 Vergelijk Craig 2013, p. 503.

52 Overweging O.

53 Jans 2010, p. 609, spreekt in dit verband over het 'interne Europese bestuursrecht'.

54 Zie uitgebreider over het vloeiende onderscheid tussen gedeeld en gemengd bestuur: J.E. van den Brink. De uitvoering van Europese subsidieregelingen in Nederland. Juridische knelpunten en uitdagingen (diss. Leiden), Deventer: Kluwer 2012, p. 66-74.

55 Zie bijvoorbeeld C.A.J.M. Kortmann, 'Wie van de drie: de algemene wet, de algemene wet of de bijzondere wet?', in: De Awb en de bijzondere wetgeving. VAR-reeks 124, Den Haag: Boom Juridische uitgevers 2000, p. 20.

56 Overweging S. Zie uitgebreider over interne harmonisatie van het algemeen bestuursrecht van de Europese lidstaten: Jans 2011, p. 620 e.v.

57 Zie bijvoorbeeld A. Drahmann, 'Tijd voor een Nederlands transparantiebeginsel, in: Europees offensief tegen nationale rechtsbeginselen? Over legaliteit, vertrouwen en transparantie, Jonge VAR-reeks 8, Den Haag: Boom Juridische uitgevers 2010, p. 143-197.

58 Zie recent over deze kwestie: E.J. Daalder, 'Actieve openbaarmaking van overheidsinformatie en de Awb', NTB 2012, p. 176 e.v.

59 Zie in dit verband F.J. van Ommeren, P.J. Huisman, G.A. van der Veen en K.J. de Graaf, Het besluit voorbij, VAR-reeks 150, Den Haag: Boom Juridische uitgevers 2013. 